\title{
Forms of Ideal Laws of State-Owned Enterprises in Harmony With Article 33 Paragraph IV of the Preamble of the 1945 Constitution of the Republic of Indonesia
}

\author{
Irit Suseno $^{1} \quad$ Sudarsono $^{2} \quad$ A. Mukthie Fadjar ${ }^{2} \quad$ Sihabudin $^{3}$ \\ 1. Doctorate Candidate of Law Faculty, Brawijaya University, Malang, Indonesia, and Lecturer at University of \\ 17 Agustus 1945, Surabaya, Indonesia. \\ 2. Professor on Law of Law Faculty, Brawijaya University, Malang, Indonesia. \\ 3.Postgraduate Program of Law Faculty, Brawijaya University, Malang, Indonesia.
}

\begin{abstract}
The form of BUMN law in Indonesia based on Law Number 19 Year 2003 concerning BUMN only exists two, namely PERSERO and PERUM, however, in the said BUMN Law it is not regulated in detail regarding what business sectors may be carried out by PERUM and what business sectors may be carried out by PERSERO. Including in the field of business that controls the lives of many people, can it be done by PERUM or PERSERO. Based on that fact, this paper will be analyzed normatively based on primary legal material and secondary legal material, on how the ideal legal form of BUMN whose business field dominates the lives of many people. From the results of the analysis it was found that the ideal law, which is in line with paragraph IV of the Preamble of The 1945 Constitution and Article 33 of the 1945 Constitution, is PERUM, because PERUM is a Business Entity whose overall capital is owned by the state, which aims to hold public and non-profit services.
\end{abstract}

Keywords: BUMN, PERUM, PERSERO, State-Owned Enterprises, Ideal Laws.

DOI: $10.7176 / J L P G / 85-12$

Publication date:May $31^{\text {st }} 2019$

\section{Introduction}

Indonesia as a welfare state has such a large role as the function of State-Owned Enterprises (BUMN) as a hand to realize social welfare for its citizens. This role is not felt if it is related to the existence of Article 33 of the 1945 Constitution. Moreover, if it is examined further, it becomes a problem of how the legal form of BUMN in the field of business controls the lives of many people. What's more so far in Law Number 19 Year 2003 also not covered about business sectors that control the lives of many people, whether it should be done by PERUM or PERSERO. This is a problem if it is related to the role of the welfare state that Indonesia carries out, as mandated by the 1945 Constitution as a constitution that applies to Indonesia. However, if viewed from the constitutional mandate as stated in Article 33 of the 1945 Constitution, it hinders the interference of the government / state in Indonesia's economic system to realize the welfare of its citizens. Thus it becomes important for the state to determine the legal form of BUMN whose business fields control the lives of many people whether in the form of PERUM or PERSERO.

\section{Methodology}

Through normative research the writer will analyze the Ideal Form of BUMN whose business field controls the lives of many people, with the mindset of sylogism that stems from research covering the scope of research on positive law inventory, which is a preliminary and basic activity to find the principles and principles of philosophy contained in Law Number 19 Year 2003 concerning BUMN and alignment in the form of BUMN with a constitutional foundation and national economic system. Furthermore,legal research in-abstracto obtained from legal inventory activities, functions as a minor premise, then through the process of sylogism will be obtained conclusio in the form of positive law in-concreto sought.

\section{a. Analysis of the Existing Condition of the Form of BUMNs that Control the Life of Many People}

Since the State of Indonesia was born, the constitution has mandated the vision of the Indonesian economy in the frame of sovereignty and social welfare. This is stated in the Preamble of the 1945 Constitution of the Republic of Indonesia in the fourth paragraph (four), namely, "Then from that to form an Indonesian state government that protects the entire Indonesian nation and all of Indonesia's bloodshed and for advancing public welfare". The sound of the paragraph is clear that Indonesian constitution is a follower of the State of Welfare. Furthermore, this general welfare is also associated with the fifth (five) Sila of Pancasila so that the basis of the general welfare is social justice for all the people of Indonesia. In accordance with the Pancasila paradigm in economic development, the economic system based on Pancasila is a democratic economic system based on family. This economic system is further mandated in Article 33 of the 1945 Constitution of the Republic of Indonesia which is one of the strategies of the independence pioneers in drafting the 1945 Constitution to carry out economic development.

Thus it is clear that the duty of the state is to provide prosperity and prosperity for the people. The strategy is 
applied to taking an important role by the state in the economic field to realize people's welfare and fulfill community needs by establishing a State-Owned Enterprise (BUMN). Explicitly this strategy is listed in Article 33 of the 1945 Constitution of the Republic of Indonesia so that as long as this article is contained in the constitution, so far the involvement of the government (BUMN) in the Indonesian economy is still needed.

The mandate of the constitution does not seem to be carried out optimally. Its existence is expected as 200 economic pillars, not infrequently the existence of various BUMNs does not increase state revenues. In addressing this problem, then the policy of privatization of BUMN was rolled out. Even this is supported by the strong flow of globalization and free markets that led the government to continue to create a business climate that can increase the power of the national economy. Involving the private sector in national economic governance, including in the management of SOEs is a choice made by the government in many countries. Changes in ownership are expected to have a positive influence on company performance.

In 1999 the Privatization of State-Owned Enterprises (SOEs) was one of the important programs of the Government and was outlined in the 1999 National Guidelines (GBHN). The GBHN mandated the Government to nourish BUMNs / BUMDs, especially those with public interests. While those whose businesses are not related to public interests are encouraged to privatize. This privatization is expected to increase productivity, profitability, efficiency, and reduce debt and reduce the burden of SOEs. Ideal privatization will foster good corporate governance (GCG), new financial resources to cover the state budget, and the interests of market expansion. According to Tanri Abeng, State Minister for State-Owned Enterprises (State-Owned Enterprises) during the Soeharto Government, there were several important objectives to hold privatization in Indonesia, one of which was to create transparency on the performance of SOEs.

The biggest privatization concern is that the government will lose economic sovereignty. Even though Article 33 paragraph (3) of the 1945 Constitution of NRI mandates production branches which control the livelihood of many people to be controlled by the state and utilized for people's welfare. Pros and Cons of the usual privatization of the community to present is in terms of the reasons for privatization, the actual understanding of the word controlled by the state, and the definition of any production branch that is important and affects the livelihood of many people. These three things essentially return to the nature of Article 33 (4) of the 1945 Constitution of the Republic of Indonesia, namely on a system of economic democracy which all leads to the welfare of the Indonesian people in the realization of an independent and reliable national economy to improve the prosperity of all people in a harmonious, equitable and equitable manner.

Mandate of Article 33 (2) "Production branches which are important to the State and which are important to the State and which control the livelihood of many people are controlled by the State. Regarding the existence of Article 33 paragraph (2) then a Day Seminar on Economic Democracy is held, 17 In December 1996 by the Association of Indonesian Independence Supporters and the National Resilience Institute, the drafting of the Decree of the People's Consultative Assembly of the Republic of Indonesia Number: / MPR /1998 concerning Economic Democracy was as follows:

1. An important production branch for the State was "Strategic production activities related to justice, security and national stability that provides welfare for all people ";

2. Production branches that control the livelihoods of many people are "the production of vital goods and services such as water, energy and public transportation" and "the production of goods and services that are felt vital to human life in a certain period of time";

3. Controlled by the State "means that it does not have to be owned by the State, except to guarantee the function of control by the State in order to promote people's welfare".

From this fact we have not found an essential understanding of the meaning of "the lives of many people" which in its development always gives birth to pros and cons in its meaning, in relation to its management. Who is allowed and who is not allowed to manage it. It turns out that we do not find noratively in existing regulations.

In the course of our journey, we understand that the Constitutional Court as a "State Institution" has the authority to interpret the 1945 Constitution. If viewed from the formulation of Article 33 paragraph 2, it can be understood that the businessman is directly managed by the state. The prodoksi branch that controls the livelihoods of many people has the meaning of public goods, there are 3 criteria for the understanding of public goods, namely:

1. Goods that cannot be excluded (non excludable);

2. Goods that are deliberately determined as public barag by the judicial system of a country;

3. Goods owned by the public due to negligence;

Departing from the facts of the law, it turns out that we have not been able to find a real definition of the definition of "controlling the livelihood of many people" But in fact we can find out that BUMNs whose business fields dominate the lives of many people, among them are:

- PT. KAI

- PLN

- DAMRI

- $\quad$ PT.PERTAMNA 


\section{- $\quad$ PDAM}

BUMN is the embodiment of the ideals and philosophy of the establishment of the state as a welfare state. A concept of welfare state shows that the state is required to play an active role in improving the welfare of its people. As Esping-Anderson stated in the book "Dream of the Welfare State" that the welfare state, basically, refers to "the active role of the state in managing and organizing the economy" which includes "the responsibility of the state to guarantee the availability of basic welfare services to a certain level its citizens ". Therefore, the ideals and philosophy of a country must be clearer and become the basis for seeing and determining the direction of BUMN. Legal regulations of SOEs in Indonesia have developed which can then be divided into 4 development periods, namely:

1. State Companies before 1960 ;

2. State enterprises according to Law Number 19 Prp Year 1960;

3. State companies according to Law Number 9 of 1969 ;

4. State companies according to Law Number 19 Year 2003 which in this law are called State-Owned Enterprises (BUMN).

Starting June 19, 2003, the BUMN Law can be used as a legal basis in the management and supervision of SOEs. The stipulation of the BUMN Law is a constitutional and strategic step carried out by the Council and the Government. The stipulation of the BUMN Law is a necessity as mandated by the MPR Decree Number IV / MPR / 1999. In addition, the BUMN Law is also a necessity in order to provide a firm, clear and strong legal foundation for the management and supervision of BUMNs in a professional, efficient, transparent and accountable manner to improve the value and performance of SOEs.

The implementation of the SOE Law can be used as an important momentum in the policy of fostering BUMN by the Government, political will, commitment and consistency of policies and the implementation of BUMN governance as a company or good corporate governance (GCG) to consistently develop the BUMN business and professional. With the enactment of this BUMN Law, it means that legally since June 2004 all the legal articles of this Law have been effective so that there will be no more doubts to implement BUMN development policies includinglaw enforcementthat is mandated in this Law.

As required by the Law, the BUMN Law has a number of principles in its preparation, namely that:

1. BUMN Laws are based on simple principles;

2. The arrangement is focused on things that are for or specific that apply specifically to SOEs;

3. The arrangement is complementary to the provisions of existing legislation, including the Limited Liability Company Law and the Capital Market Law;

4. Sectoral / public arrangements are submitted to the Sectoral Law;

5. Matters relating to capital are stipulated by Government Regulations;

6. Matters relating to management and supervision are submitted to private law (cooperative mechanism);

7. Contained the principles of Good Corporate Governance.

Through this BUMN Law, the Board and the Government have formulated the Government's direction, targets and policies in carrying out the management and supervision of SOEs. This BUMN Law is intended to fulfill the vision of developing BUMN in the future; creating a system of management and supervision of SOEs based on the principles of efficiency and productivity to improve the performance and value of SOEs; organize and reinforce the role of Government institutions and the position of Government representatives as shareholders / capital owners of BUMN; reinforce and clarify the relationship of SOEs as operators or business actors with Government institutions as regulators; and avoiding BUMNs from exploitation actions outside the corporate mechanism; and laying the basics of or the principles of good corporate governance $(G C G)$. In order to achieve these aims and objectives, the Law on BUMN is in addition to regulating provisions regarding the operation of SOEs, it also regulates the restructuring and privatization of SOEs as tools and ways to improve SOEs to achieve their aims and objectives.

The privatization of SOEs that emerged in Indonesia was caused by two factors, namely internal factors and external factors. Internal factors are changes in intellectual culture or ideas that occurred in Indonesian economists and the economic crisis that hit Indonesia. External factors are the insistence of international financial institutions (IMF and World Bank) and the influence of economic globalization. As stated by Bacelius Ruru, in Indonesia there are three main motives for privatization, namely the state of the country's finances, the enforcement of a free trade agreement, an increase in expectations from the public.

With these various factors it can be concluded that privatization is the result of an Indonesian state policy to deal with problems at that time. Wuri Andriyani also said that privatization is a way or action taken by the government to overcome the problems of state economic inefficiencies so that the way or government action in overcoming state problems is a state policy. The aim of the privatization carried out by the government currently contained in the BUMN Master Plan is also to achieve the ideal number of SOEs for the Indonesian economy. In addition, there are two important objectives among the objectives to be achieved in privatization, namely reducing the budget deficit, and fostering healthy competition. This goal can be achieved through the establishment of legal 
instruments, because law can be used as a policy tool. Wuri Andriyani also quoted Atiyah as saying that the law can be used as an instrument to achieve certain purposes and goals.

"Organizing State-Owned Enterprises efficiently, transparently and professionally, especially those whose businesses are related to public interests that are engaged in providing public facilities, defense and security industries, strategic asset management, and other business activities not carried out by the private sector and cooperatives. The existence and management of State-Owned Enterprises is stipulated by law. "

Furthermore, the reason for this efficient increase is the basis by the Indonesian government in taking privatization policies in the management of SOEs. While the mandate of the TAP MPR concerning the Privatization of SOEs reads: "Healthful State-Owned Enterprises / Regionally-Owned Enterprises, especially those whose business is related to public interests. For State-Owned Enterprises whose businesses are not related to public interest, they are encouraged to privatize through the capital market. "

With the direct appointment of the TAP MPR to be regulated further by the Act, it is deemed necessary to establish a new Law regulating SOEs in which also regulate privatization. Sufficient legal instruments in privatization function to monitor the implementation of privatization and the results of privatization for the benefit of the people. Thus, if there is privatization of SOEs, then it only matches whether the sale is in accordance with the Act or not. If it is not appropriate, then automatically the State Minister has violated the Law.

The privatization of SOEs is regulated in one special section by the BUMN Law, starting from the Third Part to the Eighth Section, Article 74 to Article 86. In detail the section consists of 6 parts with 13 articles. This BUMN Law stipulates that in the implementation of privatization, it must always pay attention to the benefits for the community, the relevant BUMN, management, employees and other stakeholders. Strictly described in article 74 of the Law on BUMN concerning the goal of privatization of SOEs is:

1. Expanding community ownership;

2. Increase efficiency and productivity;

3. Creating a healthy and competitive industrial structure;

4. Having global competitiveness and orientation, and;

5. Growing the business climate, macro economy, and market capacity.

Privatization is carried out with the hope that there will be a change in the corporate culture as a result of the inclusion of new shareholders, either through a public offering (go public) or(direct placementdirect placement). The changing corporate culture will be able to encourage an increase in company performance which will further enhance the competitiveness of companies in competing with competitors, both nationally, regionally and even globally so that in the end they will be able to contribute more to the national economy in the form of goods and services that are increasingly quality and affordable, as well as state revenues in the form of taxes that will be even greater.

Based on these targets, it can be seen later in Article 74 paragraph (2) of the BUMN Law, the purpose and objective of privatization is basically to enhance the role of the Persero in an effort to improve public welfare by expanding public ownership of the Persero, and to support national economic stability. The principles that must be considered in the privatization of SOEs, as stipulated in Article 75 of the BUMN Law, are of five types, namely the principles of transparency, independence, accountability, accountability and fairness. With privatization it is hoped that the corporate culture will change. BUMN as public servants can do more effective, efficient, and competitive in carrying out their duties to serve the community. Thus, the policy direction expected by the privatization policy is the existence of an increasingly efficient and productive state-owned enterprise management system and the achievement of the principles of Good Corporate Governance (GCG). In connection with these principles, of course this principle is not only carried out at the time of its implementation, but also very important in the preparation process.

The process of preparation and implementation must be carried out through transparency, independence, accountability, accountability, and fairness, without any intervention from other parties and in accordance with applicable laws and regulations. In addition, the preparation process for privatization needs to be consulted with various related parties so that all processes that run in privatization can be accounted to the wider community. Attention to the privatization process is quite important because if the privatization process is not guaranteed to change the structure of the domestic economy, privatization in the long run will certainly not provide any benefits to the national economy.

The BUMN Law does not provide many criteria for companies that can be privatized. In this BUMN Law, Article 76 paragraph (1) only stipulates that BUMNs that can be privatized are BUMNs that operate in competitive sectors or business sectors whose technological elements are rapidly changing. BUMNs with the first criteria can be privatized because the business sector can basically be cultivated by anyone, both state-owned and private, so that there is an increase in competition. Apart from that, of course the business sectors that the SOE is engaged in are not prohibited by legislation (sectoral policies) to be processed by the private sector and not the business sector specifically for BUMN. While the reason for the second criterion is because fast-changing technology requires a huge investment cost to replace the technology. 
Whereas the criteria for BUMNs that cannot be privatized are those in which the business sector based on legislation can only be managed by BUMN; engaged in business sectors related to defense and security; and carry out certain activities for the benefit of the community and move in the field of natural resources which by law are prohibited from being privatized. This law also regulates ways that can be implemented in privatizing BUMN. This is contained in Article 78 which shows three ways of privatization that can be done, namely the sale of shares based on the provisions of the capital market, direct selling of shares to investors, and the sale of shares to the management and / or employees concerned.

The method of privatization contained in this Act illustrates that the privatization model undertaken by Indonesia is similar to the European privatization model which focuses on privatization of SOEs, in contrast to privatization in America which focuses on the privatization of public services. In accordance with the method of privatization, a number of BUMNs in Indonesia have been privatized by the government since 1988 and some of them have registered their shares on leading stock exchanges, both at home and abroad. Prior to the birth of this BUMN Law in 2003, the privatization of BUMN in Indonesia had carried out the method (method) that had been determined by the BUMN Law. Thus, it can be said that the method legalized in the BUMN Law is a method that has become a culture in privatization in Indonesia before. This has become prevalent because the privatization policy is indeed determined by each country so that this determination must also be truly adjusted to the Indonesian situation in determining this method. Furthermore, the determination of the method used in the above privatization is carried out by the Minister as mentioned in Article 81 of the BUMN Law. In the series of privatization activities, the Minister establishes an annual privatization program which contains the results of the selection and determination of the Persero to be privatized, the method of privatization to be used and the type and range of shares to be sold. The privatization program began with the approval of the Republic of Indonesia Parliament that gave approval on the RAPBN in which there was a target of state revenues from privatization. In proposing the RAPBN to the Indonesian House of Representatives, the government included a list of BUMNs that would be privatized in the relevant fiscal year to meet the target of state revenue from the privatization planned in the RAPBN. Thus, the agreement given by the Indonesian Parliament on the intended RAPBN includes the approval of the BUMN privatization plan which will be carried out by the Government as referred to in Article 24 of Law Number 17 of 2003 concerning State Finance. The privatization plan that has been approved by the Indonesian House of Representatives is then stated in the annual privatization program. The annual privatization program in its implementation was consulted with the DPR RI as referred to in the provisions of Article 82 of Law Number 19 Year 2003 concerning BUMN.

The Minister also stipulates other supporting institutions and / or professions to assist in the implementation of privatization. However, the appointment of the supporting institutions and / or professions is also demanded by the active involvement of the management of the Persero represented in the membership of the Privatization team. To discuss and decide on the policy regarding privatization in connection with cross-sectoral policies, the government established a Privatization Committee as a coordinating body whose functions, membership and duties are regulated in Article 79 and Article 80 of the BUMN Law.

The existence of the Privatization Committee is also very necessary to be involved in the implementation of privatization as well as being consulted consistently with the DPR and disseminated to the public. This is intended to ensure that privatization is carried out transparently, professionally, and can be accounted for, and prudently. In addition, it is seen that the involvement of the Indonesian House of Representatives in the privatization process was intended to reduce the resistance of the wider community because the DPR RI was a representation of the Indonesian people.

This BUMN Law also regulates provisions regarding the procedures for privatization which are further regulated in more detail in Government Regulations. The government regulation in question is the Government Regulation of the Republic of Indonesia Number 33 of 2005 concerning Procedures for Privatization of Company Companies (Persero). In line with the BUMN Law, this Government Regulation also stipulates the criteria for any company that can be privatized and any company that cannot be privatized as well as on how to privatize and procedures for privatization procedures. Even though there is no clear and detailed description of the privatization arrangements that have been regulated in the BUMN Law.

The philosophy of the Indonesian economy which would be built is Pancasila which has been confirmed as the state philosophy of the Republic of Indonesia, complete with a provision that lowered the overall form of the statement of the 1945 Constitution,therefore, form the 1945 statement made a legal foundation or joint primary law in Indonesia that is often we know the constitution. This constitution is used as a means of controlling society in running the economy in Indonesia.

Article 33 of the 1945 Constitution is the result of thoughts carried out by Mohammad Hatta as one of the founders of the Indonesian Nation. The thought of Mohammad Hatta was guided by his thought that the country which was founded was a state of sovereignty based on Pancasila. This was also seen in Mohammad Hatta's magazine entitled Daulat Rakjat in the first edition (Year I No. 1, September 30, 1931) in his preface as follows: "The People's Sovereignty will maintain the true people's principle in all arrangements: in politics, in the economy, 
and in social interaction. For us, the people are the main, the general public has sovereignty, power, because the people are the heart of the nation. And that people is the measure of our high and low. With our people going up and with our people going down. The life of an independent Indonesia depends on all the people. There are new advocates and classes of educated people, meaning that behind them are people who are aware and aware of their sovereignty."

From the writings of Mohammad Hatta, it is clear that the formulas of Article 33 highly uphold people's sovereignty in various aspects of life and of course this is applied in Article 33 of the 1945 Constitution. Then, regarding the characteristics and system of a socialist Indonesian economy put forward by Mohammad Hatta, there are 3 factors that became the source of the birth of socialism in Indonesia summarized by Mohammad Hatta's speech in front of Sun Yat Sen University Students in Canton, October 111957 entitled Socialism in Indonesia. Based on the speech, Economic Democracy based on the 1945 Constitution and Pancasila is the teachings of a new economy that is both religious and humane, nationalistic, and democratic, which contradicts Neoliberal teachings.

This thought can also be reflected in article 33 of the 1945 Constitution of the Republic of Indonesia. The Article 33 of the 1945 Constitution of the Republic of Indonesia emphasizes the enactment of economic democracy in Indonesia, which subsequently gives birth to the principle of family and togetherness. Economic democracy in Article 33 was formulated by Mohammad Hatta who was initially formulated in the Elucidation of Article 33 of the 1945 Constitution of the Republic of Indonesia. In this explanation, the public interest was placed as the main, as stated "The prosperity of the people is not the prosperity of the people". In other words the prosperity of the people and the position of the people are placed in a substantial position. This principle also contradicts Western Democracy which fosters the existence of capitalism. Furthermore, this explanation was abolished in the amendment to the 1945 Constitution of the Republic of Indonesia. However, the normative matters contained in the explanation are included in the articles including the principles of Economic Democracy. Therefore, in essence the economic values or principles expressed by Mohammad Hatta were maintained as the principle of economic life in Indonesia.

Article 33 paragraph (4) of the 1945 Constitution of the Republic of Indonesia constitutes the implementation of the previous paragraph which is arranged in a foundation depicted in which states: "The National Economy is based on economic democracy, with the principle of togetherness, efficiency, justice, sustainability, environmentalism, independence and by maintaining the balance of progress and unity of the national economy. "In essence this foundation of economic democracy reflects the position of popular sovereignty which indeed has always been the soul of the State of Indonesia. As stated by Sri-Edi Swasono in providing input on the material content of the Draft Bill on Economic Democracy by writing that economic democracy is an economic system based on popular sovereignty for the realization of prosperity and social justice for all the people of Indonesia. Therefore it is very appropriate Article 33 of the 1945 Constitution of the Republic of Indonesia which is in Chapter XIV of the 1945 Constitution of the Republic of Indonesia which is entitled "Social Welfare" which has been refined to become "National Economy and National Welfare".

With the title of CHAPTER XIV of the 1945 Constitution of the Republic of Indonesia, the Social Welfare is placed as part of the Economy. This also shows that Indonesia has adopted the concept of a Welfare State in which the state or government not only intervenes in the welfare of the community but must be active in creating the welfare of the community. The change in the title of CHAPTER XIV of the 1945 Constitution of the Republic of Indonesia in the amendment also illustrates the new affirmation that Chapter XIV of the 1945 Constitution of the Republic of Indonesia is a chapter that regulates the national economy so that Jimly A. is called an Economic Constitution. The mention was very relevant because the 1945 Constitution of the Republic of Indonesia NRI also regulated the foundation of the Indonesian economic spirit which was the main force for the movement of the Indonesian economy. Therefore, this title also becomes the mouth of the national economy based on economic democracy. The main element of economic democracy is reducing poverty and inequality. In other words, in economic democracy, the most important thing is that someone has the right to get the best welfare and has the same opportunity to be able to carry out economic activities which ultimately can fulfill the welfare of all people.

The various controversies that exist over the privatization program in Indonesia do need to be studied more deeply than the implementation until the regulation is in law. In the realm of legislation, it often creates problems that sometimes violate the ideals of the nation or even fail to fulfill the mandate of the 1945 Constitution which became the constitution of the Indonesian nation. As is the case with the BUMN Law which also regulates privatization programs. If the concept of privatization alone has caused problems, then the government should be more observant in making arrangements in it. According to the author, there are a number of points in the BUMN Law which must indeed be considered again in the privatization arrangement which could be a weakness or inconsistency towards the 1945 Constitution.

Definition of privatization in Article 1 number (12) of Law Number 19 Year 2003 concerning BUMN states: "Privatization is the sale of shares of Persero, both partially and wholly, to other parties in order to improve the performance and value of the company, increase the benefits for the state and society, and expand the ownership 
of shares by the community".

In the article explained that privatization is the sale of shares in part and in whole. The whole word is this which contains controversy for the community. The controversy clearly has an impact on the ownership and role of BUMN listed in Article 33 paragraph (2) and paragraph (3) of the 1945 Constitution. If all shares are sold, of course the government ownership of the BUMN has gone into private ownership and changed its name instead of BUMN but a private company. Thus, it is feared that public servants will be abandoned if management changes hands to the private sector, especially foreign private sector, and of course this will injure the mandate of the 1945 Constitution towards SOEs.

The thing that needs to be reviewed before assessing the notion of privatization in the BUMN Law is the meaning of the word "controlled by the state" in Article 33 of the 1945 Constitution because this word is often misinterpreted. This is also the basis of various opinions regarding disagreement with the privatization program. The word "controlled by the state" is sometimes identified as a "master state". Thus the role of the state is more inclined as an "organizer", "economic actor" (ondernemer, enterpreuner) so that the state is considered "the owner".

The word "controlled by the state" should be emphasized in the meaning of the state as a "regulator" or "controller". Whereas according to Jimly Assiddiqie, the concept of article 33 is the concept of "management state" (welfare state) which is input from Muhammad Hatta. In the concept of the Governing State, the state is expected to continue to intervene in the market, take care of poverty, and maintain the poor. This is the basis of the inclusion of Articles 33 and 34 in the 1945 Constitution, in Chapter XIV with the title "National Economy and Social Welfare". The concept of the "management state" is of course contrary to the privatization program that originates from the concept of a capitalist state. Whereas economic democracy, according to Jimly Assiddiqie, deals with the idea of sovereignty of the Indonesian people in the life of the state which is developed with the term social democracy.

The problem is whether the privatization program can be carried out with Indonesian economic democracy which can develop into the social democracy, where privatization cannot be separated from a purely liberal capitalist economic system. But if the "management state" concept includes the state as a regulator, then the privatization program does not conflict with Article 33. In other words, privatization does not mean that the state's control or sovereignty over the BUMN is reduced or lost because the state continues to carry out sectoral regulations where privatized SOEs carry out their activities.

This is also supported by three elements of economic democracy which cover 3 aspects, from production, distribution, to business ownership, ensuring the involvement of community participation. Thus, privatization in Indonesia should be able to be done but must still have its own character and color based on its sovereignty. Actually, what is of concern is the implementation of privatization of SOEs in Indonesia and even in most other developing countries, precisely intentionally aimed at as a transformation towards a neoliberal economic system. Thus, of course it has an impact which will ultimately directly affect the implementation of the economy, so that privatization will reduce and limit the role of the state and enhance the role of the private sector in the implementation of the national economy. The problem is, with the increasing role of the private sector, the extent to which the independence of the state sector in making and implementing the regulation can be protected from the influence and pressure of the interests of the private sector. Moreover, privatization in developing countries is often marked by an increase in the concentration of capital control in the hands of a handful of people.

With the above description, it is very important if the restrictions are also regulated in this regulation. The lack of a clear definition is of course the mandate of this constitution to fade and eventually it will become a gap for foreign countries to influence the running of the economy in Indonesia, especially in people's welfare. Thus, there needs to be an affirmation in this BUMN Law regarding the limits on the sale of shares if privatized, namely only a maximum of $49 \%$. Even though this limitation is also regulated in the PP Privatization, it still seems that there are contradictions in it where there is a "whole" word in this definition. One thing that is even more important is that the government must remain as the majority shareholder so that BUMN assets are not lost and turn to the private sector and SOEs as public servants, still played by the government.

In addition, the problem that often arises is the weakness of the word "increasing benefits for the state and society". Such goals can be filled with political interests and sometimes lead to unilateral judgments by the authorities. The word "expanding share ownership by the community" here also implies an indecisive meaning of the protection of who the expansion of the shares is prioritized. Proven things often happen in Indonesia, the implementation of privatization is precisely marked by the transfer of capital or national production factors from the hands of the state to international investors. Likewise, the arrangement of the aims and objectives in article 74 of the BUMN Law states that "creating a healthy and competitive industrial structure" or "growing the macroeconomic business climate, and market capacity". According to the author, the arrangement is still vague because there is no clear provision of each of these purposes. So that it becomes one of the weaknesses of this article which does not have a clear measure. Furthermore, there are also words that still seem a broad meaning or abstract so that there is no legal firmness. This can be seen in the sound of other provisions in Article 74 of the BUMN Law, such as words contained in "creating a good / strong financial structure and management; Persero is 
competitive; increasing community participation in the Persero. The words "good", "competitive", and "the role of the community" will give birth to different meanings and coverage of each community's perception because each has a different dose so that there is no doubt that it will cause controversy.

The most important thing in regulating the purpose of privatization is "efficiency improvement" which is often also mentioned in the explanation of the BUMN Law. The problem is whether the efficiency of a company creates fair efficiency which is the principle of economic democracy listed in Article 33 paragraph (4) of the 1945 Constitution. In general, efficient economy is identical to maximum gain if it is in an economic business entity and maximum satisfaction in the economic transactions of a person. This is where the manifestation of economic liberalism that operates through free markets can open the way for market forces and ultimately destroy the people's sovereignty. In other words, a free market will displace the poor rather than displace poverty. This is what is currently happening in Indonesia.

Furthermore, the most important setting is about positive and negative lists. Article 76 paragraph 1 stipulates that SOEs to be privatized must be competitive industries / business sectors or industries / business sectors whose technological elements change rapidly. While the negative list arrangement starts from the General Explanation of the BUMN Law which states that privatization can only be done as long as the SOE activity sector is not prohibited by law for privatization. The weaknesses of the two arrangements above are the possibility of a competitive business sector and rapid technological changes but related to the interests of the community, such as water or electricity. Clearly for these two rules there has been a norm conflict. This problem also becomes more complex when there is also the obscurity of the meaning of "production branches that are important for the state" or "the lives of many people" in Article 33 of the 1945 Constitution which until now has been difficult to translate. Various opinions on the branches of production that control the lives of many people, one of which was expressed by Dibyo Prabowo, namely: "basic needs" and "public utilities" can be the livelihood of many people. Because it is the livelihood of many people, the amount should be sufficient. If the amount is sufficient, the price will be affordable to the public.

The researcher argues that what was said by Dibyo Prabowo had deficiencies which prioritized the government's evaluation in assessing whether the production branch needed to be mastered or not. If according to the Government it is not important for the state but controls the livelihood of many people, it is still felt that it does not need to be controlled by the State. Even if we look again at Article 33 paragraph (2) of the 1945 Constitution, then there is not a requirement of choice which is characterized by the word "or" but there is an affirmation of the word "and". So according to the author, those two things should be an inseparable requirement in grouping which production branches are controlled by the state. However, what is very difficult to find in the meaning of Article 33 paragraph (2) of the 1945 Constitution is the affirmation of what branches of production must be controlled by the State because various opinions say that it depends on the values and perceptions of a society that is strongly influenced by the dimensions of space and time.

Once again that privatization related to "production branches that are important to the state" or "the livelihood of many people", which must be controlled by the state, is an opportunity and dilemma, depending on the definition of the word "mastered" above. The meaning of "mastered" discussed above does not necessarily mean that the branches of production must be controlled by the state, but the Government has the authority to regulate the production for the benefit of the state so that the production branches can be owned or controlled by the state. This is where the role of the state in monitoring and acting if ownership or the consequences arising from ownership disturbs the public interest. It is this dynamic nature that makes this meaning difficult to standardize so that the government and society do indeed have to be more observant about the natural resources they have and that are a strategic source for the people of Indonesia.

Furthermore, the provisions that are still abstract and indecisive in the regulation on privatization in the BUMN Law can be seen, among others, in the use of the following words:

1. Article 75: "paying attention" to the principles of transparency, independence, accountability, accountability and fairness;

2. Article 80: "invites" parties "who need to be invited".

3. Article 84: "clash" of interests;

4. Article 85: must maintain the confidentiality of information "as long as the information is not yet open".

These words are still abstract formulas which do not explain the limits and scope of each of what is meant in the article.

Judging from the above problems, actually this BUMN Law still has weaknesses and is abstract in nature so that the arrangement in it is not comprehensive to achieve the ideals of privatization referred to by stakeholders previous Indonesian economicwho initiated the thinking of the Indonesian economy. With the existence of these weaknesses and abstracts, it will gradually impact the economy built on the spirit of the Indonesian Nation to be eliminated little by little. Therefore, according to the author if indeed this privatization is considered to have begun to be feasible in Indonesia, it is necessary to first design what kind of privatization system will be brought by Indonesia so that the spirit of economic democracy based on people's economy will not disappear when 
privatization is carried out in the field.

\section{b. The Form of BUMNs that Control the Life of Many People in Accordance with Article 33 of the} 1945

Constitution Indonesia's economic law still requires legislation and efforts to harmonize national law with international law are also very necessary in order to accommodate various needs in the management of the current national economy this has changed as a result of new phenomena in the business world, both on a national, regional and international scale.

Urgent reform in the economic field is the juridical basis of the national economic system as stated in Article 33 of the 1945 Constitution. In order for the national economy to be managed properly, clear guidelines are needed, for example in a constitutional regulation. Because until now there are still multiple interpretations of Article 33 of the 1945 Constitution. As an example of State-Owned Enterprises (SOEs) as one of the businesses that was established by the state under Article 33 of the 1945 Constitutionhas a function and strategic role in national economic development for SOE has entered almost all sectors of the economy that is until December 31, 1997 alone SOE managing assets of around Rp. 461.6 trillion and some of them even control the upstream industry which is very vital and strategic.

Actually Article 33 of the 1945 Constitution is a mandate from the Proclamation and the 1945 Constitution concerning the Pancasila national economy. What is meant by this is an arrangement of the Indonesian economy, whose center is the prosperity of the people. What is meant by this is to prioritize the achievement of people's prosperity, and above that is planned in terms of things and other fields of people's lives.

Since the operationalization of SOEs faces many big problems and challenges, for example, most BUMNs suffer significant losses because they are managed inefficiently and with low productivity so that various forms of state enterprises do not have the ability to compete in business competition both in domestic and international markets. Some of the factors that led to the management of most of the BUMNs were inefficient so that they suffered losses and became a burden on state finance, among others: (i) the legal status and structure of the BUMN organization, it is unclear whether BUMN is an economic actor with full autonomy or only as an executor or part from the organizational structure of a department; (ii) the majority of BUMNs do not havecorporate culturecorporate, vision and mission; (iii) lack of entrepreneurial spirit and professionalism of HR managing SOEs, so performance and productivity are very low: and (iv) SOEs are not managed withgood corporate governance principlesas a result of too much government interference or dominant in the company's operations.

In 1999 the Privatization of State-Owned Enterprises (SOEs) was one of the important programs of the Government and was outlined in the 1999 National Guidelines (GBHN). The GBHN mandated the Government to nourish BUMNs / BUMDs, especially those with public interests. While those whose businesses are not related to public interests are encouraged to privatize. This privatization is expected to increase productivity, profitability, efficiency, and reduce debt and reduce the burden of SOEs. Ideal privatization will foster good corporate governance (GCG), new financial resources to cover the state budget, and the interests of market expansion. According to Tanri Abeng, State Minister for State-Owned Enterprises (State-Owned Enterprises) during the Soeharto Government, there were several important objectives to hold privatization in Indonesia, one of which was to create transparency on the performance of SOEs. Furthermore, Tanri showed that there were evident 178 cases of KKN practices that occurred in various sector BUMNs, and none of them occurred in BUMNs that had gone public.

The biggest privatization concern is that the government will lose economic sovereignty. Even though Article 33 paragraph (3) of the 1945 Constitution of NRI mandates production branches which control the livelihood of many people to be controlled by the state and utilized for people's welfare. Pros and Cons of the usual privatization of the community to present is in terms of the reasons for privatization, the actual understanding of the word controlled by the state, and the definition of any production branch that is important and affects the livelihood of many people. These three things essentially return to the nature of Article 33 (4) of the 1945 Constitution of the Republic of Indonesia, namely on a system of economic democracy which all leads to the welfare of the Indonesian people in the realization of an independent and reliable national economy to improve the prosperity of all people in a harmonious, equitable and equitable manner. The importance of privatization of SOEs is supported by the existence of Law Number 19 Year 2003concerning BUMN (BUMN Law). The presence of the Act continued the BUMN privatization program that had previously been carried out. This law is generally used as a legal basis in the management and supervision of SOEs. As a strong legal basis, actually the BUMN Law is a powerful legal umbrella for the government to carry out the mandate of the privatization policy of SOEs so that the main goal of SOEs as a company can be achieved by stakeholders maximization (welfare for shareholders, consumers, employees and the government).

Privatization of BUMN according to Article 1 number 12 of Act Number 19 of 2003 concerning State-Owned Enterprises is carried out on BUMN in the form of Persero. As is known, Article 9 of Law Number 19 of 2003 concerning State-Owned Enterprises determines, SOEs consist of Persero and Perum. 
In connection with this, Article 1 number 2 of Law Number 19 of 2003 concerning State-Owned Enterprises defines a Persero as an SOE in the form of a limited liability company whose capital is divided into shares in which all or at least $51 \%$ (fifty one percent) shares are owned by The Republic of Indonesia, whose main goal is to pursue profits. Whereas Perum according to Article 1 number 3 of Act Number 19 of 2003 concerning State-Owned Enterprises is a State-Owned Enterprise whose entire capital is owned by the state and is not divided into shares, which aims at public benefit in the form of high-quality and pursuing goods and / or services. profits based on the principles of company management. Thus, BUMN can be in the form of a business entity that aims to gain profits and is also in the form of a company whose main purpose is not to seek profits, but rather inpublic servicesto the community to guarantee social welfare.

The philosophical company is intended to carry out the mandate of Article 33 paragraph (2) and paragraph (3) of the 1945 Constitution, namely that production branches which are related to the livelihood of many people and management of natural resources are controlled by the state for great prosperity of the people. On that basis, the form of a state-owned enterprise that is compatible with Article 33 paragraph (2) and paragraph (3) is a company whose capital is not divided into shares that are oriented towards company profits, thus preventing the existence of private ownership or by a group of people towards SOEs. Housing is also designed as a business entity which guarantees the availability of state-owned enterprises that dominate the production of the crowds and oriented to promote the general welfare as aline IV of the preamble(preamble) of the Constitution of 1945.

In line with this, Indonesia as a welfare state(welfarestate)as explained in the previous discussion it was required to play an active role in advancing public welfare. This is a manifestation of the conception of thewelfare state, which was originally initiated to change the paradigm of the night watchman (nachkwachterstaat) in which the state is only a passive power entity in managing the happiness of its citizens.

Historically, thewelfare state wasborn as the biological child of socialism which was popular in the 19th century, to counter the capitalist-liberalism which in the juridical study was described by Wilhelm Lunstedt who stated, Law is nothing but the very life of mind and mind in organized groups and conditions that make possible peaceful co-existence of the problems of individuals and social groups and corporations for ends of more existence and propagation. Moving on from that explanation, public welfare is the main subject in legal and social discourse.

The main key in the welfare state is the issue of guaranteeing people's welfare by the state. Regarding this matter, Jurgen Habermas argues that the guarantee of the welfare of all people is the main thing for a modern country. Furthermore, according to Habermas, the welfare guarantees of all the people referred to are realized in the protection of the risk of unemployment, accident, illness, old age, and death of the breadwinner must be covered largely through the welfare provisions of the state.

Judging from the description of the welfare state theory and in relation to the form of BUMN which in accordance with Article 33 of the 1945 Constitution, it can be explained that BUMNs are instruments or tools of the Indonesian state in an effort to promote public welfare. Therefore, SOEs are actually formed to become a forum for active state intervention in realizing the greatest prosperity of the people and advancing social welfare as assigned by the IV paragraph of thePreambleof the 1945 Constitution and as mandated by Article 33 The 1945 Constitution. For this reason, there should be no private / private interference including foreign parties in matters of branches of production which control the livelihoods of many people and the management of natural resources in Indonesia. Thus, there must be no privatization of business sectors that control the livelihoods of many people and the field of natural resource management. On this basis, SOEs engaged in the business of natural resources and production branches that control the livelihoods of many people must be in the form of Perum (not Persero) to cover the space for privatization of SOEs that can hamper the country's efforts to promote public welfare and people's prosperity. Thus, a contrario must be understood that BUMNs in the form of Persero can only be carried out on sectors / fields that do not affect the livelihoods of many people and non-natural resource fields.

In connection with these arguments, it is not without reason that Perum is the right form of BUMN and in line with the IV paragraph ofPreambleand Article 33 of the 1945 Constitution, because as mentioned above, in the legal literature the Perum company has characteristics as The following:

- The meaning of his business is to serve the public interest (the interests of production, distribution and consumption as a whole) and at the same time to foster profits. The business is carried out by adhering to the requirements for efficiency, effectiveness and economy cost accounting and management effectiveness as well as goodserviceto the community or its customers.

- $\quad$ Legal status and regulated by law (with wetsduiding).

- Generally it is engaged in the field of vital services (public utilities).

- The government may stipulate that some businesses that are public utilities do not need to be regulated, compiled or impromptu as a state enterprise.

- Have their own name and wealth and freedom of movement such as private companies to enter into or enter into agreements, contracts, and other company relationships.

- Can be prosecuted and demanded, and the legal relationship is regulated in a civil law relationship (privaatrechtterlijk). 
- Capital is entirely owned by the state from separated state assets, and can have and obtain funds from domestic and foreign credits or from bonds (from the public).

- In principle financially must be able to stand alone, except if the government's politics regarding the tariff of prices does not permit the achievement of this goal.

- Led by a Board of Directors.

- The employee is an employee of a state company which is regulated separately outside the provisions that apply to civil servants or private companies / businesses (State) Persroans.

- The organization, duties, authority, responsibility, responsibility and how to account for it, as well as supervision and so on, are specifically regulated, the main points of which will be reflected in the Law governing the formation of the state enterprise.

- Because of its nature, if one of them is in the form of a public utility, then if it is deemed necessary for the public interest in politics the tariff can be determined by the government.

- The company's annual report which contains a profit and loss balance sheet and wealth balance sheet is submitted to the government.

Based on these characteristics, PERUM is a company that carries out government functions as a public service to the public and at the same time as a supplier of state finances. The status of employees is not civil servants so it is not subject to civil servant regulations and also to the regulations of private employees. Between the Bureau of Companies and Public Companies is still based on the management of government bureaucracy.

\section{References}

Ahmad Erani Yustika, 2007, Perekonomian Indonesia: Satu Dekade Pascakrisis Ekonomi, Malang: Badan Penerbit Fakultas Ekonomi Universitas Brawijaya

Bacelius Ruru, Pondasi Revitalisasi: Memahami UU BUMN, Riant Nugroho (Ed.), BUMN Indonesia: Isu, Kebijakan, dan Strategi, Jakarta: PT Alex Media Komputindo,

Bacelius Ruru, 2002, Privatisasi BUMN, dalam Safri Nugraha, Privatisasi di Berbagai Negara, Jakarta: Lentera Hati,

Boardman dan Vining dalam Riant Nugroho dan Randy R.W, 2008, Manajemen Privatisasi BUMN, Jakarta: PT Elex Media Komputindo,

Dibyo Prabowo, 1989, Pelaku dan Politik Ekonomi Indonesia, Yogyakarta

Esping-Anderson, 2006, Social Foundation for Pontindustrial Economies, dalam Buku Darmawan Triwibowo dkk, Mimpi Negara Kesejahteraan, Jakarta: Pustaka LP3ES,

Gunarto Suhardi, 2007, Revitalisasi Badan Usaha Milik Negara, Yogyakarta: Universitas Atma Jaya

Gianfranco Poggi, 1992, The Development of the Modern State "Sosiological Introduction, California: Standford University Press,

Huruf 12 dalam Arah Kebijakan Ketetapan Majelis Permusyawaratan Rakyat Republik Indonesia Nomor IV/MPR/1999 tentang Garis-Garis Besar Haluan Negara Tahun 1999-2004

Huruf 28 dalam Arah Kebijakan Ketetapan Majelis Permusyawaratan Rakyat Republik Indonesia Nomor IV/MPR/1999 tentang Garis-Garis Besar Haluan Negara Tahun 1999-2004

Ishak Rafick, 2010, BUMN Expose, Jakarta: PT Ufuk Publishing House,

I Wangsa Widjaja, Mohammad Hatta, 1983, Kumpulan Pidato II, Jakarta: Inti Dayu Press

Ishak Rafick, 2010, BUMN Expose, Jakarta: PT Ufuk Publishing House,

Jimly Asshiddiqie, 2010, Konstitusi Ekonomi, Jakarta: PT Kompas Media Nusantara

Jimly Assiddiqie, 2002. Konsolidasi Naskah UUD 1945 Setelah Perubahan Keempat, Jakarta: Pusat Studi Hukum Tata Negara, Fakultas Hukum Universitas Indonesia

Materi Muatan Rancangan Undang-Undang tentang Demokrasi Ekonomi yang merupakan masukan dari SriEdi Swasono yang dilaksanakan pada tanggal 11 Desember 2008

Marwah M. Diah, 2003, Restrukturisasi BUMN di Indonesia, Jakarta: Literata Lintas Media, hal. 11

Ronny Hanitijo Soemitro, 1988, Metodologi Penelitian Hukum dan Jurimetri, Jakarta, Ghalia Indonesia,

Riant Nugroho dan Randy R.W, 2008, Manajemen Privatisasi BUMN, Jakarta: PT Elex Media Komputindo,

Sri-Edi Swasono, 1992, Demokrasi Ekonomi: Keterkaitan Usaha Partisipatif Vs Konsentrasi Ekonom, Direktorat Publikasi Ditjen Pembinaan Pers dan Grafika (Departemen Penerangan RI) (Ed.),

Sri-Edi Swasono, Indonesia is Not For Sale : Sistem Ekonomi Untuk sebesar-besarnya Kemakmuran Rakyat, dalam Sri Edi Swasono, Bahan Rapat Dengar Pendapat Umum DPR RI Tentang Kerakyatan dan Demokrasi Ekonom

Sumantoro, 1998, Hukum Ekonomi, Jakarta: UI Press

Soemardi, 2010, Teori Umum Hukum dan Negara : Dasar-Dasar Ilmu Hukum Normatif Sebagai Ilmu Hukum Deskriptif-Empirik, Bandung: Bee Media Indonesia,

Tom Gunadi, 1986, Sistem Perekonomian menurut Pancasila dan UUD 1945, Bandung: Angkasa

Pandji Anoraga, 1995, BUMN, Swasta dan Koperasi, Tiga Pelaku Ekonomi, Jakarta: PT Dunia Pustaka Jaya, 
Pancasila Sebagai Ideologi: Dalam Berbagai Bidang Kehidupan Bermasyarakat, Berbangsa, dan Bernegara, Percetakan Negara RI

Wuri Andriyani, "Telaah Hukum Pada Privatisasi BUMN", Arena Hukum, Nomor 1 Tahun 1 Januari 